\title{
PROGRAM HALAL JABUNG MUSHROOM TOURISM SEBAGAI AKSELERASI DESA SEJAHTERA MANDIRI BERBASIS EKONOMI KREATIF
}

\author{
Nour Athiroh Abdoes Sjakoer ${ }^{1}$, Masyhuri Machfudz ${ }^{2}$ \\ ${ }^{1}$ Fakultas Matematika dan Ilmu Pengetahuan Alam, Universitas Islam Malang \\ email: nur_athiroh_mlg@yahoo.co.id \\ ${ }^{2}$ Fakultas Pertanian, Universitas Islam Malang \\ email: masyhuri033@gmail.com
}

\begin{abstract}
ABSTRAK
Sesuai Undang Undang No.6 Tahun 2014 tentang Desa pasal 78 dan penjelasannya terdapat 2 pendekatan dalam pembangunan 'desa membangun' upaya yang dilaksanakan masyarakat desa/kelembagaan desa dan upaya yang dilaksanakan di luar desa/stakeholder. Desa Jabung ini telah diwisuda oleh Kementerian Sosial RI Khofifah Indra Parawasa menjadi Desa Sejahtera Mandiri pada 12 Maret 2018. Temuan hasil pengabdian 'dikemas' dalam bentuk KKN Tepadu science dan pengabdian dari produk makanaan, maka perlu produk makanan siap saji dilakukan uji ke-HALAL-annya dengan berkolaborasi halah center Unisma. Hasil pengabdian menunjukkan bahwa upaya peningkatan dan pengoptimalan potensi desa harus terus digalakkan guna mewujudkan misi pemerintah untuk menjadikan desa Jabung sebagai Desa Sejahtera Mandiri berbasis Seni dan Ekonomi Kreatif. Konsep Halal Jabung Mushroom Tourism merupakan konsep baru yang cocok dan layak untuk terus dikembangkan, hal ini sesuai dengan banyaknya masyarakat Jabung yang melakukan budidaya jamur. Selain itu iklim mayoritas masyarakat Jabung yang 99 \% memeluk agama Islam menjadikan desa Jabung layak untuk diorbitkan menjadi destinasi wisata halal Indonesia guna mendukung program pemerintah yang menjadikan negeri ini sebagai kiblat wisata halal dunia. Atas kenyataan di atas, maka disarankan bahwa bagi pengembangan Halal Jabung Mushroom Tourism yakni dengan pengoptimalan sinergi berbagai stakeholder diatas, selain itu keterbukaan informasi harus terus ditingkatkan guna identifikasi lebih lanjut secara komprehensif kawasan Halal Jabung Mushroom Tourisma agar nantinya setiap konsep yang dibuat tidak salah sasaran dan konsep yang dibangun dapat memberikan efek percepatan (akselerasi) ekonomi kreatif menuju desa mandiri di wilayah Desa Jabung, Kec. Jabung, Kab. Malang.
\end{abstract}

Kata Kunci: halal desa jabung; desa sejahtera mandiri.

\section{PENDAHULUAN}

Globalisasi dan Desentralisasi manajemen suatu derah telah mengantarkan banyak desa di berbagi daerah Indonesia menjadi maju dan unggul serta bisa bersaing dengan desa lain di seluruh penjuru dunia. Pemerintah desa bersama dengan seluruh lapisan masyarakat mengaktualisasikan diri berlomba-lomba membangun desanya untuk menjadi desa terbaik di level nasional maupun internasional. Menurut UU No. 6 Tahun 2014 pasal 68 Tentang Desa menyebutkan setidaknya ada enam prinsip yang harus dianut dalam pengembangan pembangunan desa yaitu:

Pertama; pemberdayaan, yang dimaksud dengan pemberdayaan adalah penguatan masyarakat dalam bidang ekonomi, politik maupun dalam bidang sosial budaya. 
Pemberdayaan dalam bidang ekonomi dilakukan dengan memberikan kesempatan atau peluang tumbuh dan berkembangnya usaha-usaha ekonomi rakyat. Pemberdayaan politik adalah memberikan kesempatan kepada masyarakat untuk ambil bagian dalam pengambilan keputusan pembangunan. Sedangkan pemberdayaan dalam bidang sosial budaya adalah memberikan kesempatan kepada masyarakat untuk membangun kepercayaan diri, membangun kelembagaan sosial yang mandiri, membudayaakan ketaatan atas kesempatan yang telah diambil, memberikan kesempatan kepada masyarakat untuk belajar dari pengalaman dan mendorong pengembangan masyarakat dari akar budaya dan jati dirinya.

Kedua; perlibatan perempuan selama ini perempuan hanya diberi peran atau tugas yang banyak, tetapi jarang diberi hak dalam pengambilan keputusan. Perlibatan perempuan yang dimaksud dalam pembangunan desa, yaitu memberikan kesempatan kepada kaum perempuan untuk terlibat aktif dalam proses pengambilan keputusan pembangunan.

Ketiga, keterbukaan yang merupakan perwujudan pertanggungjawaban pelaksanaan pembangunan kepada masyarakat yang diwujudkan dengan keterbukaan informasi. Dengan adanya keterbukaan akan melahirkan kepercayaan, ketertutupan akan melahirkan ketidakpercayaan masyarakat terhadap pemerintah dalam melaksana pembangunan. Masyarakat selain terlibat dalam proses pengambilan keputusan sampai proses evaluasi pembangunan.

Keempat, keswadayaan pembangunan desa, pada dasarnya berasal dari masyarakat dan oleh masyarakat sendiri. Oleh karena itu, prinsip keswadayaan tidak hanya dilihat dari sisi ketersediaan masyarakat untuk membiayai pembangunan tetapi juga harus dilihat dari sisi pemecahan masalah, pengelolaan dan prakarsa. Dalam prinsip keswedayaan, masyarakat yang merencanakan, melaksanakan dan membiayai pembangunan. Kalau ada bantuan dari pemerintah, seperti dana desa sifatnya hanya sebagai stimulan dan perangsang yang sewaktu-waktu akan berakhir.

Kelima, keberlanjutan dalam hal ini perencanaan dan manajemen pengelolaan desa harus dirancang untuk keberlanjutan. Agar keberlangsungan manajemen desa yang baik dapat derjalan sepanjang zaman.

Keenam, partisipasi yakni adanya keterlibatan atau ikut sertanya masyarakat, dalam kegiatan pembangunan baik secara mental maupun pikiran serta tenaga yang dilaksanakan dengan sadar dan dengan penuh tanggung jawab untuk mencapai tujuan yang telah ditetapkan bersama.

Salah satu cara alternatif untuk membangun dan memajukan suatu desa adalah dengan meningkatkan pengembangan desa wisata. Menurut informasi yang dilansir dari kompas.com Arif Yahya selaku sebagai ketua Menteri Pariwisata menyebutkan bahwasannya desa wisata dapat menjadi langkah untuk memajukan perekonomian desa di Indonesia. Kementerian Pariwisata bekerja sama dengan Kementerian Desa, Pembangunan Daerah Tertinggal, dan Transmigrasi serta Kementerian Koperasi dan Usaha Kecil dan Menengah untuk mengembangkan desa yang memiliki potensi pariwisata.

Di Indonesia ada beberapa contoh desa wisata yang sudah terkenal di seluruh penjuru dunia. Salah contoh desa wisata tersebut adalah Bali. Pemerintah Provinsi Bali menargetkan pengembangan 100 desa wisata hingga tahun 2018. Sementara Ubud sebagai daerah wisata dikembangkan rumah singgah untuk wisatawan. Sedangkan contoh yang lain adalah Kampung Wisata Jodipan (KWJ) Warna-warni di Kota Malang yang telah merubah kondisi psikologis, ekonomi, sosial, lingkungan, budaya dan gaya hidup masyarakat kampung Jodipan. 
Tren wisata dunia saat ini adalah wisata halal. Wisata ini menjadi tren yang terus berkembang di sejumlah negara tak terkecuali di Indonesia. Sebagai negara yang memiliki penduduk dengan mayoritas beragama Islam, Indonesia dinilai memiliki potensi yang sangat besar untuk pengembangan wisata ini. Dikutip dari cnnindoensia.com menginformasikan pada tahun 2016, Indonesia berhasil menyabet 12 dari 16 penghargaan pada World Halal Tourism Award di Abu Dabi diantara 12 penghargaan itu, tiga di antaranya milik Lombok. Ketiganya untuk kategori World's Best Halal Beach Resort, World's Best Halal Tourism Website, serta World's Best Halal Honeymoon Destination.

Dewasa ini pemerintah Indonesia memiliki program pariwisata dengan menjadikan Indonesia sebagai kiblat wisata halal dunia. Wisata halal Indonesia saat ini masih terfokus pada sebagian parsial destinasi wisata yang ada, belum kepada konsep wisata halal secara menyuluruh layaknya konsep desa wisata. Melihat peluang dan potensi yang besar ini konsep desa wisata halal perlu dikembangkan dan mendapatkan perhatian serius dari pemerintah. Pemerintah bekerjasama dengan berbagai stakeholder untuk meweujudkan kawasan desa wisata halal.

Salah satu desa yang potensial untuk dikembangkan konsep desa wisata halal adalah desa Jabung. Desa Jabung merupakan salah satu dari 15 desa yang terletak di kecamatan Jabung, kabupaten Malang-Jawa Timur. Kredibilitas desa Jabung sudah tidak dapat dipertanyakan lagi, terbukti dengan telah diresmikannya Desa Jabung sebagai Desa Sejahtera Mandiri oleh Ibu Khofifah Indar Parawansa selaku sebagai Menteri Sosial Indonesia era ini (www.tribunews.com). Desa Sejahtera Mandiri merupakan program Kementerian Sosial yang berfokus pada upaya mencari solusi atas masalah kesejahteraan sosial di suatu desa seperti fakir miskin, penyandang disabilitas, anak terlantar, lansia terlantar, pekerja migran bermasalah, narkoba, dan lain-lain. Kondisi tersebut diatasi dengan program pemberdayaan sosial yang diarahkan untuk mendorong warga mampu mandiri dan memenuhi kebutuhan dasarnya sehingga kualitas hidup meningkat. Pada tahun 2015, Desa Jabung mendapatkan pencanangan Desa Sejahtera Mandiri melalui Pelaksanaan Program Renovasi Rumah Tidak Layak Huni (RUTILAHU) dan Kelompok Usaha Bersama (KUBE). Kemensos memberikan bantuan stimulasi Rutilahu sebesar Rp 10 juta untuk setiap kepala keluarga.

Seiring dengan kedudukan desa Jabung sebagai Desa Sejahtera Mandiri, desa Jabung juga telah mendedikasikan dirinya menjadi Desa Sejahtera Mandiri yang berbasis Seni dan Ekonomi Kreatif. Kini desa Jabung terus menunjukkan prestasi dan eksistensinya sebagai desa swakarya tingkat nasional. Aparatur Desa dibantu dengan staffnya serta seluruh warganya terus bersinergi dengan pihak eksternal untuk menciptakan program-program yang edukatif, kreatif, potensial dan bersifat memberdayakan serta meningkatkan kesejahteraan seluruh warga desa Jabung.

Berdasarkan berbagai uraian dan fakta diatas maka penulis memiliki konsep karya ilmiah yang berjudul "Halal Jabung Mushromm Tourism sebagai Akselerasi Desa Sejahtera Mandiri berbasis Ekonomi Kreatif". Karya ini masih tergolong baru dan didedikasikan untuk kemajuan desa Jabung pada khususnya dan desa lain pada umumnya.

Adapun rumusan masalah dalam penelitian ini adalah sebagai berikut: (i) bagaimana konsep Halal Jabung Mushroom Tourism dalam sudut pandang Islam? (ii) bagaimana grand design konsep Halal Jabung Mushroom Tourism? dan (iii) bagaimana potensi dan tantangan konsep Halal Jabung Mushroom Tourism?

Adapun tujuan dalam program pengabdian ini adalah sebagai berikut: (i) untuk mengetahui konsep Halal Jabung Mushroom Tourism dalam sudut pandang Islam; (ii) untuk mengetahui grand design konsep Halal Jabung Mushroom Tourism dan (iii) untuk mengetahui potensi dan tantangan konsep Halal Jabung Mushroom Tourism. 
Manfaat praktis Halal Jabung Mushroom Tourism adalah sebagai wahana sosioekonomi pedesaan dan peningkatan serta pengembangan desa wisata mandiri berbasis ekonomi kreatif. Bagi masyarakat luas sebagai acuan pemanfaatan potensi desa guna meningkatkan kesejahteraan ekonomi masyarakat pedesaan. Bagi akademisi sebagai pendorong peningkatan kualitas akademik dalam melakukan studi lapangan dan menciptakan pembaharuan. Bagi pemerintah sebagai acuan dalam pembangunan daerah solusi permasalahan yang semakin kompleks serta mendukung program pemerintah menjadikan Indonesia sebagai kiblat wisata halal dunia.

Pada tinjauan pustaka pengabdian terdahulu penulis menggunakan telaah penelitian yang berasal dari karya ilmiah terdahulu yang berkaitan dengan peningkatan ekonomi pedesaan berbasis wisata dengan permasalahan penulis pada penelitian yang berjudul "Jabung Halal Mushroom Tourism sebagai Akselerasi Ekonomi Kreatif Menuju Desa Mandiri". Beberapa telaah penilitian tersebut diantaranya:

1. Kiki (2017) tentang Inovasi Pemuda Dalam Mendukung Ketahanan Ekonomi Keluarga (Studi Di Kampung Warna-Warni Kelurahan Jodipan, Kecamatan Blimbing, Kota Malang). Penelitian ini bertujuan untuk menganalisis inovasi pemuda mahasiswa Universitas Muhammadiyah Malang yang tergabung kelompok Guys Pro dalam merubah image kumuh RW 02 Kelurahan Jodipan dan menganalisis produk inovasi pemuda yakni Kampung Warna Warni Jodipan (KWJ) dalam mendukung ketahanan ekonomi keluarga. Hasil penelitian menunjukkan bahwa inovasi Guys Pro merubah image kumuh di RW 02 Kelurahan Jodipan dengan menciptakan Kampung WarnaWarni. Kampung Warna-Warni Jodipan menjadi pilot project kampung wisata di Kota Malang. Promosi yang dilakukan secara terus-menerus melalui online dan offline menarik minat pengunjung untuk mengunjungi KWJ. Kunjungan wisatawan memberikan peluang bagi masyarakat untuk menyediakan barang dan jasa yang dibutuhkan oleh pengunjung. Saat ini sebagian besar masyarakat Jodipan berwirausaha di rumah masing-masing. Selain itu, ibu-ibu PKK di RW 02 Kelurahan Jodipan berpartisipasi dalam memanajemen wisata KWJ. Perubahan image KWJ sebagai kampung wisata di Kota Malang mendukung ketahanan ekonomi keluarga bagi warga RW 02 Kelurahan Jodipan.

2. Zakaria (2014) tentang Konsep Pengembangan Kawasan Desa Wisata di Desa Bandungan Kecamatan Pakong Kabupaten Pamekasan. Dalam penelitian ini dilakukan penentuan faktor-faktor yang dapat mendukung pengembangan kawasan desa wisata dan perumusan konsep pengembangan kawasan desa wisata di Desa Bandungan. Tujuan penelitian ini adalah untuk menentukan konsep pengembangan kawasan desa wisata di Desa Bandungan Kecamatan Pakong, Kabupaten Pamekasan. Penelitian ini menghasilkan konsep pengembangan secara spasial dan non spasial. Adapun konsep spasialnya dengan menyediakan rute perjalanan wisata, menyediakan sarana transportasi khusus menuju kawasan desa wisata dan menyediakan fasilitas pendukung kegiatan wisata. Sedangkan konsep non spasialnya dengan menjadikan adat istiadat sebagai peraturan kegiatan wisata, mengembangkan kawasan desa wisata berbasis agrowisata, menyediakan fasilitas penginapan berkonsep tanean lanjheng, menyediakan toko souvenir, menyediakan fasilitas rumah makan, memberikan pelatihan kepada masyarakat, menyediakan tempat rekreasi, membuat web tentang kawasan desa wisata, melibatkan masyarakat dalam proses pengembangan dan menerapkan peraturan zonasi.

3. Heny dkk (2013) tentang Pengembangan Desa Wisata Berbasis Partisipasi Masyarakat Lokal di Desa Wisata Jatiluwih Tabanan, Bali yang bertujuan mengkaji keterlibatan masyarakat lokal dalam pengembangan desa wisata dan merumuskan model 
pengembangan desa wisata yang mengedepankan partisipasi masyarakat lokal menunjukkan bahwa bahwa pengembangan desa wisata di Jatiluwih belum melibatkan masyarakat, peranan pemerintah terlihat dominan, padahal bila mengacu pada pendekatan tata kelola pemerintah yang bersih dan berkelanjutan peran pemerintah diharapkan menjadi fasilitator dengan memberikan peran dan manfaat yang lebih besar kepada masyarakat lokal. Diperlukan kemauan politik pemerintah untuk mengurangi perannya dalam pengembangan desa wisata dengan membuka ruang bagi masyarakat untuk berpartisipasi.

Berdasarkan informasi yang dilansir dari tribunnewas.com menyebutkan bahwa Desa Jabung kec. Jabung kab. Malang merupakan salah satu desa yang diresmikan oleh Ibu Khofifah Indar Parawansa (Menteri Sosial RI) sebagai Desa Sejahtera Mandiri Berbasis Seni dan Ekonomi Kreatif. Atas prestasi yang diraihnya tersebut mendorong aparat pemerintah desa Jabung untuk terus berinovasi dan melakukan terobosan-terobosan yang bersifat memberdayakan dan mensejahterakan seluruh masyarakat desa Jabung, diantaranya adalah menjadikan Jabung sebagai pusat produksi aneka kerajian topeng khas malang, pengembangan sanggar tari edukatif, produksi keripik singkong, pengolahan limbah plastik menjadi genteng, dan peternakan sapi perah.

Peningkatan kesejahteraan terus dilakukan oleh aparat desa Jabung, yang terbaru adalah peningkatan perekonomian warga melalui budi daya jamur tiram (Pleurotus Ostreatus). Jamur Tiram merupakan jamur yang dipilih dikarenakan merupakan jamur pangan dengan ciri-ciri umum tubuh buah berwarna putih atau krem dan tudungnya berbentuk setengah lingkaran mirip cangkang tiram dengan bagian tengah agak cekung. Alasan lain adalah cara budi daya yang mudah, banyak disuka lidah orang Indonesia, pangsa pasar yang luas, serta dapat dikreasikan dan kombinasikan dengan aneka jenis pangan yang lain menjadikan jamur tiram sebagai komoditas jamur utama budidaya masyarakat desa Jabung. Berdasarkan data yang diperoleh dari kantor kelurahan desa Jabung saat ini terdapat kurang lebih 50 warga yang melakukan pembudidayaan jamur yang tersebar di empat dusun, yakni dusun Boro Jabung terdapat 6 warga, dusun Mindi ada 15 warga, dusun Gunung Kunci ada 10 warga, dan 19 warga terletak di dusun Krajan. Diperkirakan jumlah ini akan terus naik seiring dengan kesuksesan para pelaku budi daya jamur. Saat ini pemerintah desa Jabung hanya fokus pada pengelolaan budi daya Jamur dan belum sampai ke level pendampingan yang bersifat pengolahan hasil panen Jamur, diperlukan sinergitas dari berbagai lembaga dengan pemerintah desa Jabung dan masyarakatnya untuk menjadikan potensi Jamur ini dikelola lebih produktif dan eksploratif sehingga meningkatkan nilai positif Desa Jabung menjadi Desa Mandiri Berbasis Seni dan Ekonomi Kreatif.

\section{Wisata Halal}

Sebenarnya yang umum dikenal selama ini adalah wisata syariah atau wisata religi. Pengertiannya tentu tak melulu berwisata ke lokasi-lokasi religius seperti makam-makam Walisongo seperti yang selama ini banyak dilakukan orang. Jika wisata religi lebih mengedepankan aspek lokasi atau objek dan sejarah tempat wisata, maka wisata halal lebih mengedepankan aspek pelaku atau wisatawannya. Dikutip dari kompasiana.com Akademisi M. Battour dan M. Nazari Ismail mendefinisikan wisata halal merupakan semua objek atau tindakan yang diperbolehkan menurut ajaran Islam untuk digunakan atau dilibati oleh orang Muslim dalam industri pariwisata. Definisi ini memandang hukum Islam (syariah) sebagai dasar dalam penyediaan produk dan jasa wisata bagi konsumen (dalam hal ini adalah Muslim), seperti hotel halal, resort halal, restoran halal dan perjalanan halal. Menurut definisi ini, lokasi kegiatan tidak terbatas di negara-negara Muslim semata. 
Juga mencakup barang dan jasa wisata yang dirancang untuk wisatawan Muslim di negara Muslim dan negara non-Muslim. Selain itu, definisi ini memandang bahwa tujuan perjalanan tidak harus bersifat keagamaan. Jadi perjalanan bisa dengan motivasi wisata umum. Berdasarkan Global Muslim Travel Index (GMTI) yang menjadi acuan standar wisata halal di dunia adalah destinasi ramah keluarga, layanan dan fasilitas di destinasi yang ramah muslim, dan kesadaran halal serta pemasaran destinasi.

\section{Ekonomi Kreatif}

John Howkins dalam bukunya The Creative Economy: How People Make Money pertama kali memperkenalkan istilah ekonomi kreatif. Howkins menyadari lahirnya gelombang ekonomi baru berbasis kreativitas setelah melihat pada tahun 1997, Howkins menjelaskan ekonomi kreatif sebagai "kegiatan ekonomi dalam masyarakat yang menghabiskan sebagian besar waktunya untuk menghasilkan ide, tidak hanya melakukan hal-hal yang rutin dan berulang. Karena bagi masyarakat ini, menghasilkan ide merupakan hal yang harus dilakukan untuk kemajuan. Karakteristik ekonomi kreatif diantaranya; (a). diperlukan kolaborasi antara berbagai aktor yang berperan dalam industri kreatif, yaitu cendekiawan (kaum intelektual), dunia usaha, dan pemerintah yang merupakan prasyarat mendasar; (ii) berbasis pada ide atau gagasan; (iii) pengembangan tidak terbatas dalam berbagai bidang usaha dan (iv) konsep yang dibangun bersifat relatif.

Departemen Perdagangan Republik Indonesia merumuskan ekonomi kreatif sebagai upaya pembangunan ekonomi secara berkelanjutan melalui kreativitas dengan iklim perekonomian yang berdaya saing dan memiliki cadangan sumber daya yang terbarukan. Definisi yang lebih jelas disampaikan oleh United Nations Development Progamme (UNDP) yang merumuskan bahwa ekonomi kreatif merupakan bagian integratif dari pengetahuan yang bersifat inovatif, pemanfaatan teknologi secara kreatif, dan budaya.Indonesia merupakan Negara dengan banyak suku dan budaya, maka setiap daerah yang memiliki sebuah kebudayaan dapat mempresentasikan budayanya dengan cara-cara yang unik.

\section{Desa Mandiri}

Menurut Lendi (2015) Desa Mandiri berarti Desa mempunyai kekuatan secara ekonomi, budaya dan sosial melalui pembangunan dan pemberdayaan masyarakat secara berkesinambungan. Meski tidak mudah, hal ini merupakan amanat UU Desa dalam rangka memperkuat Desa. Hal ini penting, bahwa persoalan Desa tidak boleh menjadi konsumsi kalangan elit (politisi, akademisi, pelaku elit program) saja. Isu dan agenda Desa mandiri mesti mencerminkan kepentingan paling aktual dari masyarakat Desa sendiri. Isu dan agenda didaratkan pada ingatan dan problematika keseharian rakyat Desa. Persoalan kebutuhan dasar masyarakat Desa menyangkut soal pangan, sandang, papan, pendidikan dan kesehatan serta terbangunnya iklim usaha ekonomi masyarakat yang sehat dan berkembang. Negara (Pemerintah) telah menetapkan kewenangan dan urusan yang ditangani oleh Desa demikian juga dengan dukungan anggaran Dana Desa yang bersumber dari APBN. Di samping itu UU No. 6 tahun 2014 tentang Desa menekankan pada pentingnya kemandirian Desa, penataan perencanaan pembangunan Desa, peningkatan kapasitas Kepala Desa dan Perangkat Desa, serta peningkatan sumber-sumber keuangan desa.

\section{METODE}

Jenis penulisan yang digunakan dalam karya ilmah ini adalah penulisan kualitatif dengan pendekatan deskriptif. Penulisan kualitatif ialah penulisan yang menghasilkan data deskriptif berupa data tertulis yang bertujuan memberikan gambaran keadaan, sistem ataupun inovasi secara sistematis (Neolaka, 2014). 
Jenis data yang digunakan dalam karya ilmiah ini adalah data primer dan data sekunder. Data primer berupa wawancara langsung kepada pihak yang terkait saat melaksanakan kegiatan Kuliah Kerja Nyata (KKN). Data sekunder adalah data yang diperoleh secara tidak langsung atau melalui perantara kedua. Adapun metode pengumpulan data yang digunakan di dalam penulisan ini adalah dengan metode:

Kepustakaan, studi kepustakaan dilakukan dengan mengumpulkan literaturliteratur yang bersumber dari buku-buku akademik, jurnal ilmiah, laporan survei nasional dan artikel pada laman internet dengan sumber yang dapat dipertanggungjawabkan. Dokumenter, studi dokumenter dilakukan dengan cara membaca dan menganalisis literatur-literatur yang relevan dengan permasalahan penulisan.

Intuitif subjektif, intuitif subjektif dilakukan dengan melibatkan pendapat-pendapat penulis untuk menganalisis lebih mendalam terkait dengan permasalahan yang sedang dibahas. Lokasi dilakukan pada saat kegiatan Kuliah Kerja Nyata (KKN) kelompok 1 di Desa Jabung, kec. Jabung, kab. Malang dimulai tanggal 29 Januari - 28 Februari 2018.

Proses analisis data dilakukan dengan menyajikan data-data yang terkumpul dan kemudian dipaparkan dalam pembahasan. Disamping itu, sintesis dilakukan dengan menggunakan studi silang (cross link) antara data yang terkumpul dan konsep yang ditawarkan. Kemudian dapat diambil titik utama yang diolah menjadi beberapa kesimpulan dan saran. Proses anlisis data pada karya ilmiah ini dilakukan melalui beberapa tahapan, yaitu: (i) pengumpulan data (data collection), (ii) reduksi data (data reduction), (iii) penyajian data (data display) dan (iv) pemaparan dan penarikan kesimpulan (conclution drawing and verfication).

Analisis ini dilakukan secara mendalam dengan narasi yang akan diuji melalui uin opinion agar validasi data dapat dipertanggungjawabkan. Namun demikian, penelitian ini akan dilakukan secara berkelanjutan dengan ukuran variabel angka numerik sehingga dapat dilakukan analisis secara kuantitatif.

\section{HASIL DAN PEMBAHASAN}

\section{Konsep Halal Jabung Mushroom Tourism dalam Sudut Pandang Islam}

Halal Jabung Mushroom Tourism adalah sebuah ide baru atas konsep pembentukan agrowisata halal berbasis Jamur yang didesain untuk memaksimalkan potensi desa Jabung sebagai Desa Sejahtera Mandiri berbasis Seni dan Ekonomi Kreatif yang telah diresmikan kementerian Sosial Indonesia Ibu Khofifah Indar Parawansa pada Maret 2017 tahun lalu. Konsep ini sekaligus mendukung program pemerintah untuk menjadikan Indonesia sebagai kiblat wisata halal dunia.

Menurut ketua Majelis Ulama Indonesia (MUI) kota Padang, Sumatera Barat, Duski Samad menyimpulkan bahwa Halal Tourism Destination, Moslem Frendly Tourism Destination dan Wisata Syariah adalah konsep berbeda dalam sebutan namun satu makna yaitu wisata halal (www.tribunews.com). Wisata halal bisa diperhadapkan dengan wisata boleh, sunah atau haram. Hadirnya istilah wisata halal merupakan jawaban terhadap pandangan miring, dan tidak produktif pada dunia parawisata. Padahal realitasnya wisata itu adalah bagian dari kebutuhan hidup manusia. Citra wisata tercoreng bukan karena substansinya, akan tetapi disebabkan prilaku dari pihak pengelola, masyarakat sekitar daerah wisata dan/atau wisatawan yang berbuat tidak halal.

Norma tentang wisata dapat dipahami dari firman Allah SWT dalam QS. Qurais, (106):1-4 yang artinya "1. Karena kebiasaan orang-orang Quraisy, 2. (yaitu) kebiasaan mereka bepergian pada musim dingin dan musim panas. Maka hendaklah 
mereka menyembah Tuhan Pemilik rumah ini (Ka'bah), 4. Yang telah memberi makanan kepada mereka untuk menghilangkan lapar dan mengamankan mereka dari ketakutan.

Imam Syafi'i menukilkan "Innal fi al asfaar khamsyah fawaid, tafarraju hammi, wa iktishab ma'isyah, wa al 'ulum, wa al adab wa shuhbatul maajid". Artinya: Sesungguhnya pada berwisata memiliki lima manfaat yaitu untuk rekreasi, refresing, ekonomi sebagai sumber kehidupan, pengembangan ilmu pengetahuan, pembentukan budaya dan mendapatkan mitra yang baik. Ibnu Taymiyah, seorang pejuang yang berani menghadapi penguasa menjadikan wisata sebagai tempat yang baik, ia berkata: "kalau saya di bunuh saya mati syahid, kalau saya di usir itu saya dapat kesempatan untuk berwisata ke tempat di luar kampung saya".

Mencermati ayat dan pandangan ulama di atas, dapat dikatakan bahwa berwisata itu adalah baik, dianjurkan dan bagian penting dalam kehidupan umat manusia. Masalahnya ketika wisata dihubungkan dan dikaitkan dengan kata syariah, maka ada persepsi yang memandang ekstrim terhadap syariah, karena faktor politik atau simbol Islam, atas dasar itu menggunakan konsep wisata halal dipercaya dapat mengurangi resistensi dan mudah mensosialisasikan dalam masyarakat yang kuat nilai-nilai agama. Wisata halal sekaligus juga dapat meluruskan stigma negatif terhadap wisata itu sendiri.

\section{Grand Design Konsep Halal Jabung Mushroom Tourism}

Secara umum wisata halal dapat diartikan sebagai kegiatan wisata yang dikhususkan untuk memfasilitasi kebutuhan berwisata ummat Islam. Menurut Akademisi M. Battour dan M. Nazari Ismail mendefinisikan wisata halal yaitu semua objek atau tindakan yang diperbolehkan menurut ajaran Islam untuk digunakan atau dilibati oleh orang Muslim dalam industri pariwisata (studipariwisata.com). Perlu diketahui, kebutuhan konsumen muslim terhadap wisata halal ini secara umum meliputi kemudahan untuk beribadah, mendapatkan makanan halal, mendapatkan nilai tambah dari perjalanan, serta terjaganya dari kemaksiatan dan kemungkaran.

Istilah wisata halal baru mulai dikenal sejak 2015 ketika sebuah event World Halal Tourism Summit (WHTS) digelar di Abu Dhabi, UAE. Sebelumnya dunia pariwisata hanya mengenal sebagai muslim tour atau semisalnya. Dalam event ini WHTS berusaha menyadarkan bahwa pangsa pasar dari wisata halal amatlah besar dan perlu untuk terus dikembangkan.WHTS bahkan memprediksi pada tahun 2019 nanti tidak kurang dari 238 milyar USD berputar di dunia wisata halal (di luar haji dan umrah), ini artinya pertumbuhan dunia wisata halal melejit hampir mendekati $90 \%$ lebih cepat dibanding wisata umum dari tahun ke tahun. Lebih hebatnya, jumlah itu terus tumbuh dari waktu ke waktu.

Salah satu contoh dari bentuk pelayanan ini misalnya Hotel yang tidak menyediakan makanan ataupun minuman yang mengandung alkohol dan memiliki kolam renang serta fasilitas spa yang terpisah untuk pria dan wanita. Selain hotel, transportasi dalam industri pariwisata halal juga memakai konsep Islami. Penyedia jasa transportasi wajib memberikan kemudahan bagi wisatawan muslim dalam pelaksanaan ibadah selama perjalanan. Kemudahan ini bisa berupa penyediaan tempat sholat di dalam pesawat, pemberitahuan berupa pengumuman maupun adzan jika telah memasuki waktu sholat selain tentunya tidak adanya makanan atau minuman yang mengandung alkohol dan adanya hiburan Islami selama perjalanan (disbudpar.acehprov.go.id). Ada 6 (enam) kebutuhan pokok wisatawan Muslim yang diidentifikasi dalam studi Crescent Rating di 130 negara yaitu: (i) makanan halal, (ii) fasilitas shalat, (iii) kamar mandi dengan air untuk wudhu, (iv) pelayanan saat bulan 
Ramadhan, (v) pencantuman label non halal (jika ada makanan yang tidak halal) dan (vi) fasilitas rekreasi yang privat (tidak bercampur baur secara bebas).

Berdasarkan uraian diatas maka Grand Design Konsep Halal Jabung Mushroom Tourism merupakan rencana besar konsep pembentukan dan pengembangan agrowisata halal berbasis jamur di desa Jabung dengan skema sebagai berikut:

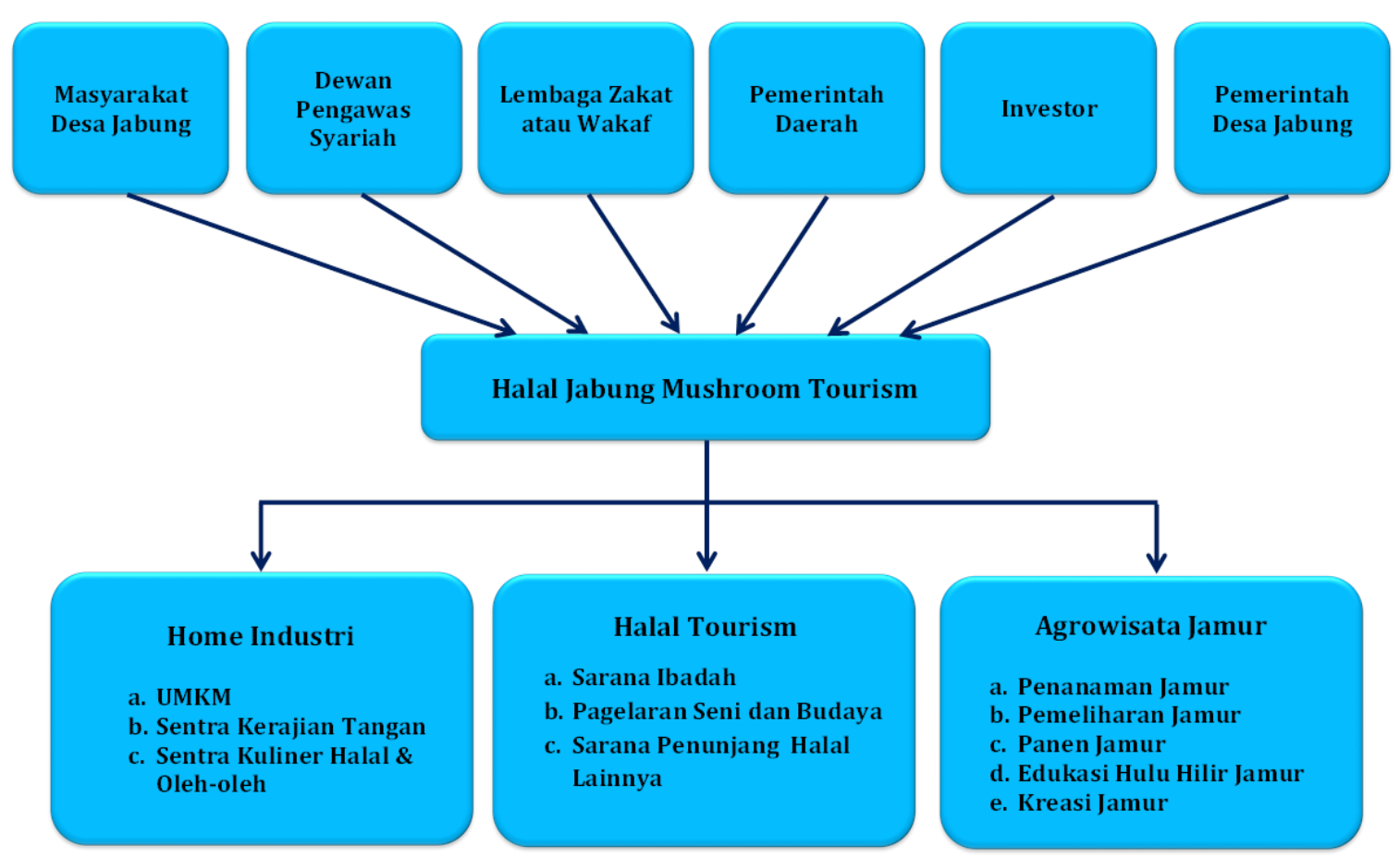

Gambar 1. Skema Halal Jabung Mushroom Tourism

Keterangan:

a. Pada skema ini masyarakat desa jabung, dewan pengawas syariah, lembaga zakat dan/atau wakaf, pemerintah daerah, investor dan pemerintah desa Jabung mengintegrasikan diri bekerjasama dalam rangka pembentukan dan pengembangan Halal Jabung Mushroom Tourism. Akad atau kontrak kerjasama harus dengan akad syariah dengan sistem bagi hasil diantara pihak yang terkait. Dewan syariah dalam skema ini memiliki peran sebagai pengawas syariah atas dilaksanakannya konsep, sedangkan yang lain mengawasi secara bersama-sama dari sisi pengembangan, pemberdayaan dan jalannya konsep ini.

b. Seluruh pihak yang bekerjasama merumuskan konsep Halal Jabung Mushroom Tourism yang terdiri dari tiga konsep yaitu; (i) home Industri : UMKM, sentra kerajinan tangan, sentra kuliner halal dan oleh-oleh, (ii) halal Tourism : Sarana ibadah, pegelaran seni dan budaya, serta sarana penunjang lainnya, dan (iii) agrowisata Jamur : Penanaman jamur, pemeliharaan jamur, panen jamur, edukasi hulu hilir jamur ,dan kreasi jamur.

\section{Potensi Konsep Halal Jabung Mushroom Tourism}

Menurut Kamus Besar Bahas Indonesia (KBBI) Potensi adalah kemampuan yang mempunyai kemungkinan untuk dikembangkan. Adapun potensi dari konsep ini adalah eksistensi Jamur Tiram.

Jamur Tiram memiliki banyak manfaat yaitu mengandung karbohidrat yang tinggi, terapi makanan sehat dan alami sehingga jamur tiram dapat diolah dengan berbagai macam kreasi diantanya keripik jamur, bakso jamur, nugget jamur, siomay jamur, jamur krispi dan aneka kreasi yang lain. 
Jamur Tiram juga dapat dijadikan ladang bisnis dengan potensi keuntungan yang sangat besar dengan keuntungan bersih (netto) berkisar antara 20-30\%. Keuntungan ini bisa meningkat menjadi 30-50 \% jika dijual dalam bentuk olahan, misalnya jamur goreng krispi.

\section{Dampak Sosial dan Ekonomi}

Dampak sosial dalam konsep ini diantarnya; (i) bertambahnya kesempatan kerja dan mutu kualitas kerja; (ii) kesejahteraan meningkat; (iii) mengurangi sikap indivudualisme yang tinggi dari berbagai pihak dan (iv) menumbuhkan semangat kerja sama dan saling memiliki.

Dampak ekonomi dalam pembangunan pariwisata adalah dampak negatif atau dampak positif yang terjadi terhadap lingkungan ekonomi dalam kehidupan masyarakat sebagai akibat perkembangan pariwisata terhadap perubahan pekerjaan dan pendapatan masyarakat, pola pembagian kerja, kesempatan kerjra dan berusaha. Halal Jabung Mushroom Tourism memiliki dampak yang positif bagi berbagai pihak yang terkait diantaranya; (i) bagi Masyarakat Desa Jabung konsep ini dapat meningkatkan pendapatan mereka dengan cara melakukan produksi kreatif yang dapat di; (ii) lirik dan diminati wisatawan; (iii) Dewan Pengawas Syariah dapat memperoleh pendapatn jasa dari pengawasan yang telah dilakukannya; (iv) Lembaga Zakat dan/atau Wakaf dapat memberikan edukasi seputar optimalisasi zakat dan/atauwakaf kepada pengelola dan seluruh pihak yang terkait tentang wajibnya zakat jika harta telah mencapai nisab serta pentingnya wakaf produktif untuk mendukung pembangunan perkenomian bangsa; (v) pemerintah Daerah dapat meningkatakn sumber pendapatan asli daerahnya; (vi) Investor mendapatkan imbalan berupa bagi hasil dari dana yang telah diinvestasikannya sesuai dengan kesepakatannya dan (vii) Pemerintah Desa Jabung dapat meningkatkan sumber pendapatan desanya dari konsep.

\section{KESIMPULAN}

Berdasarkan penjelasan diatas maka penulis menyimpulkan bahwa upaya peningkatan dan pengoptimalan potensi desa harus terus digalakkan guna mewujudkan misi pemerintah untuk menjadikan desa Jabung sebagai Desa Sejahtera Mandiri berbasis Seni dan Ekonomi Kreatif. Konsep Halal Jabung Mushroom Tourism merupakan konsep baru yang cocok dan layak untuk terus dikembangkan, hal ini sesuai dengan banyaknya masyarakat Jabung yang melakukan budidaya jamur.

Selain itu iklim mayoritas masyarakat Jabung yang $99 \%$ memeluk agama Islam menjadikan desa Jabung layak untuk diorbitkan menjadi destinasi wisata halal Indonesia guna mendukung program pemerintah yang menjadikan negeri ini sebagai kiblat wisata halal dunia.

Atas dasar pembahasan dan simpulan diatas maka saran bagi pengembangan Halal Jabung Mushroom Tourism yakni dengan pengoptimalan sinergi berbagai stakeholder diatas, selain itu keterbukaan informasi harus terus ditingkatkan guna identifikasi lebih lanjut secara komprehensif kawasan Halal Jabung Mushroom Tourisma agar nantinya setiap konsep yang dibuat tidak salah sasaran dan konsep yang dibangun dapat memberikan efek percepatan (akselerasi) ekonomi kreatif menuju desa mandiri di wilayah desa Jabung, kec. Jabung, kab. Malang. 


\section{DAFTAR RUJUKAN}

Al Quran dan Terjemahannya. 2014. Jakarta: Departemen Agama RI. UU No. 6 Tahun 2014 pasal 68 Tentang Desa.

Departemen Perdagangan Republik Indonesia (www.kemendag.go.id) (diakses 06 Maret 2018).

Kamus Besar Bahasa Indonesia. 2013. Edisi ke-empat. Jakarta: Departemen Pendidikan dan RI.

Neolaka, Amos. 2014. Metode Penelitian dan Statistik. Bandung: Remaja. Rosdakarya. Howkins, J. 2001. The Creative Economy: How People Make Money from Ideas. London: Penguins Books.

Kiki, Prisca Wulandari. 2017. Inovasi Pemuda Dalam Mendukung Ketahanan Ekonomi Keluarga (Studi Di Kampung Warna-Warni Kelurahan Jodipan, Kecamatan Blimbing, Kota Malang). Yogyakarta. Vol.23 No.3, Desember 2017. Diambil dari http://journal.ugm.ac.id/jkn (diakses 05 Maret 2018).

Zakaria, Faris, Rima Dewi Supriharjo. 2014. Konsep Pengembangan Kawasan Desa Wisata di Desa Kebudayaan Bandungan Kecamatan Pakong kabupaten Pamekasan. Surabaya.Vol.3 No.2, 2014. Diambil dari http:// ejurnal.its.ac.id/index.php/teknik ( diakses 05 Maret 2018).

Heny, Made Urmila Dewi, Chafid Fandeli, M. Baiquni. 2013. Pengembangan Desa Wisata Berbasis Partisipasi Masyarakat Lokal di Desa Wisata Jatiluwih Tabanan, Bali. Bali Vol. 3 No. 2, Agustus 2013. Diambil dari http://journal.ugm.ac.id/kawistara ( diakses 05 Maret 2018).

Kantor Pemerintah Desa Jabung Kec. Jabung Kab. Malang https://www.kompasiana.com (diakses tanggal 06 Maret 2018)

https://gmti.crescentrating.com (diakses tanggal 06 Maret 2018)

https://disbudpar.acehprov.go.id (diakses tanggal 06 Maret 2018)

https://studipariwisata.com (diakses tanggal 06 Maret 2018)

https://www.id.undp.org (diakses tanggal 06 Maret 2018)

https://www.scribd.com (diakses tanggal 06 Maret 2018)

https://www.cnnindonesia.com (diakses tanggal 05 Maret 2018)

https://www.tribunnews.com (diakses tanggal 05 Maret 2018)

https://www.kompas.com (diakses tanggal 05 Maret 2018) 